\title{
STUDI AWAL PENGAMBILAN KEMBALI ALUMINIUM DARI LIMBAH KEMASAN SEBAGAI ALUMINA
}

\author{
Dewi Widyabudiningsih dan Endang Widiastuti \\ Jurusan Teknik Kimia Polban, \\ J1. Geger Kalong Hilir Desa Ciwaruga \\ e-mail : Thewidyabudiningsih.@yahoo.com \\ endwidy@yahoo.com
}

\begin{abstract}
Abstrak
Pada dewasa ini, selain besi, aluminium merupakan logam yang paling banyak digunakan di sektor industri dibandingkan dengan logam lain, salah satunya sebagai kemasan. Kemasan yang terbuat dari aluminium ini banyak digunakan untuk mengemas produk makanan dan minuman, yang jika sudah digunakan isinya, maka wadah kemasan ini akan menjadi sampah. Sampah ini termasuk sampah anorganik yang tidak akan terurai secara alami dan memerlukan pengolahan tertentu untuk menguraikannya. Proses pengambilan kembali aluminium dari limbah ini dilakukan dengan metode gravimetri yaitu melarutkan limbah tersebut dengan $\mathrm{HCl} 18 \%$. Untuk memisahkan ion-ion yang tidak diinginkan, maka digunakan pereaksi tambahan seperti asam suksinat 5\%, 2 gram urea dan 5 gram ammonium klorida. Untuk menghilangkan kandungan air dari endapan maka dilakukan proses pembakaran. Pembakaran ini juga berfungsi untuk menghasilkan endapan murni yang diperoleh dari proses pengambilan aluminium sebagai alumina dari limbah kemasan tersebut. Pada suhu ruang $\left(27^{\circ} \mathrm{C}\right), \mathrm{HCl} 18 \%$ merupakan pelarut yang baik untuk melarutkan sampel yang mengandung aluminium. Alumina terbanyak didapat dari sampel yang berbentuk pizza pans yaitu 8,8203 gram dari 5 gram sampel, dengan persentase aluminium sebesar 93,39\%.
\end{abstract}

Kata Kunci :

Furnace, recovery, gravimetri, digestion, kemasan

\section{PENDAHULUAN}

Sampah kini merupakan masalah yang cukup rumit bagi kota-kota besar di Indonesia, seperti Jakarta dengan tempat pembuangan akhir sampah (TPA) Bantar Gebangnya, Bandung dengan TPA Leuwigajahnya, kemudian Bogor dengan TPA Bojongnya. TPA merupakan masalah utama dari semua ini, karena bagi penduduk yang tempat tinggalnya dekat dengan kawasan TPA tersebut sering dirugikan oleh polusi yang ditimbulkan dari sampah yang telah membusuk, seperti bau yang tidak sedap.

Sampah terbagi menjadi dua jenis, yaitu sampah organik dan sampah anorganik. Sampah organik tidak terlalu menimbulkan masalah yang rumit dalam penanggulangannya karena sampah organik ini dapat terurai oleh organisme-organisme pengurai yang terdapat di dalam tanah atau dengan kata lain dapat terurai secara alami, sedangkan untuk sampah anorganik tidak dapat terurai secara alami. Sehingga hal ini dapat menjadi masalah dalam pengolahan sampah secara keseluruhan, terutama yang berasal dari bekas kemasan makanan dan minuman.

Dalam industri makanan dan minuman, aluminium sering digunakan sebagai kemasan/pembungkus makanan dan minuman, sebagai contoh, kaleng minuman ringan, kaleng untuk buah atau manisan buah, cetakan kue yang dilapisi aluminium foil dan aluminium foil yang langsung digunakan untuk pembungkus makanan. Kemasan ini hanya digunakan untuk sekali pakai dan langsung dibuang menjadi sampah, sehinggga akan menambah jumlah sampah yang sudah ada. Oleh karena itu dicoba untuk mengolah sampah tersebut dengan cara mengambil kembali (recovery) kandungan aluminium yang terdapat dalam kemasan tersebut dalam bentuk alumina (A12O3), sehingga dapat digunakan kembali sebagai 
logamnya atau sebagai senyawa aluminiumnya.

Aluminium oksida adalah oksida amfoter dengan rumus kimia $\mathrm{A} 12 \mathrm{O} 3$. Hal ini umumnya disebut sebagai alumina, atau korundum dalam bentuk kristalnya, serta banyak nama lainnya, mencerminkan terjadinya secara luas di alam dan industri. Penggunaan yang paling signifikan adalah dalam produksi logam aluminium, meskipun juga digunakan sebagai bahan abrasif karena sifat kekerasannya dan sebagai refraktor karena bahan untuk titik lebur yang tinggi. Alumina juga digunakan sebagai insulator (penghambat) panas dan listrik yang baik.

Alumina berperan penting dalam ketahanan logam aluminium terhadap perkaratan dengan udara. Logam aluminium sebenarnya amat mudah bereaksi dengan oksigen di udara. Aluminium bereaksi dengan oksigen membentuk aluminium oksida (alumina), yang terbentuk sebagai lapisan tipis yang dengan cepat menutupi permukaan aluminium. Lapisan ini melindungi logam aluminium dari oksidasi lebih lanjut. Ketebalan lapisan ini dapat ditingkatkan melalui proses anodisasi. Beberapa alloy (paduan logam), seperti perunggu aluminium, memanfaatkan sifat ini dengan menambahkan aluminium pada alloy untuk meningkatkan ketahanan terhadap korosi. ( h t t p s : / / w a w a s a $\mathrm{n}$ i $1 \mathrm{~m} \mathrm{u}$ kimia,wordpress.com/2014)

Alumina, merupakan komponen utama dalam bauksit bijih aluminium yang utama.. Bijih bauksit terdiri dari $\mathrm{A} 12 \mathrm{O} 3, \mathrm{Fe} 2 \mathrm{O} 3$, and $\mathrm{SiO} 2$ yang tidak murni. Campuran ini dimurnikan terlebih dahulu melalui Proses Bayer:

panas $\rightarrow 2 \mathrm{NaAl}(\mathrm{OH}) 4$

$$
\mathrm{A} 12 \mathrm{O} 3+3 \mathrm{H} 2 \mathrm{O}+2 \mathrm{NaOH}+
$$

Fe2O3 tidak larut dalam basa yang dihasilkan, sehingga bisa dipisahkan melalui penyaringan. $\mathrm{SiO} 2$ larut dalam bentuk silikat $\mathrm{Si}(\mathrm{OH}) 62-$. Ketika cairan yang dihasilkan didinginkan, terjadi endapan $\mathrm{Al}(\mathrm{OH}) 3$, sedangkan silikat masih larut dalam cairan tersebut. $\mathrm{Al}(\mathrm{OH}) 3$ yang dihasilkan kemudian dipanaskan sesuai reaksi di bawah ini :

$2 \mathrm{Al}(\mathrm{OH}) 3+$ panas $\rightarrow \mathrm{Al} 2 \mathrm{O} 3$
$+3 \mathrm{H} 2 \mathrm{O}$

A12O3 yang terbentuk adalah alumina. (https://id.wikipedia.org/wiki/ Aluminiumoksida)

Logam aluminium berwarna putih, mengkilat, mempunyai titik leleh sekitar $660^{\circ} \mathrm{C}$, moderat lunak jika dalam keadaan murni, tetapi jika dibuat paduan dengan logam lain akan menjadi kuat serta sangat ringan. Serbuk aluminium terbakar dalam api menghasilkan debu awan alumina sesuai persamaan reaksi :

$$
4 \mathrm{Al}(\mathrm{s})+3 \mathrm{O} 2(\mathrm{~g}) \quad 2 \mathrm{Al} 2
$$

$\mathrm{O} 3(\mathrm{~s})$

Logam Al bereaksidengan asam kuat membebaskan gas hidrogen sedangkan dengan basa kuat membentuk aluminat sesuai persamaan reaksi (Dewi Ikmah,2014):

Reaksi antara Aluminium dengan asam adalah sbb :

$$
2 \mathrm{Al}(\mathrm{s})+6 \mathrm{H} 3 \mathrm{O}+(\mathrm{aq}) 2
$$

$\mathrm{Al} 3+(\mathrm{aq})+6 \mathrm{H} 2 \mathrm{O}(\mathrm{l})+3 \mathrm{H} 2(\mathrm{~g})$

Reaksi antara Aluminium dengan basa adalah sbb:

$6 \mathrm{H} 2 \mathrm{O}(\mathrm{l}) 2[\mathrm{Al}(\mathrm{OH}) 4]-(\mathrm{aq})+3 \mathrm{H} 2(\mathrm{~g})$

\section{METODOLOGI}

\subsection{Bahan dan Alat}

Bahan yang digunakan sebagai sampel berasal dari limbah kemasan yang mengandung aluminium seperti, kaleng minuman, aluminium foil, loaf pans, pizza pans, pie pans dan cetakan kue ukuran kecil. Penelitian ini dilakukan di laboratorium penelitian Jurusan Teknik Kimia Polban.

Sedangkan bahan dan peralatan yang digunakan adalah sebagai berikut :

Peralatan yang digunakan dalam penelitian ini, meliputi furnace, hot plate, masker, labu takar, gelas kimia, gelas ukur, pipet volume, corong, kertas saring, batang pengaduk dan cawan porselen. Bahan yang digunakan terdiri dari :

- limbah kemasan yang mengandung aluminium dari berbagai jenis produk 
- $\quad \mathrm{HCl}, \mathrm{H} 2 \mathrm{SO} 4$ danHNO3 yang digunakan sebagai pelarut aluminium.

- $\mathrm{NH} 4 \mathrm{Cl}$, urea, $\mathrm{NH} 4 \mathrm{OH}$, asam suksinat dan aquades sebagai bahan tambahan.

\subsection{Prosedur}

\subsubsection{Percobaan Awal}

Percobaan awal dilakukan dengan menggunakan pelarut $\mathrm{HCl} 36 \%$, $\mathrm{H} 2 \mathrm{SO} 498 \%$ dan $\mathrm{HNO} 370 \%$, untuk memastikan pelarut mana yang lebih baik untuk melarutkan kemasan tersebut. Proses pelarutan dilakukan dengan dua kondisi yang berbeda yaitu, pelarutan pada suhu kamar dan pelarutan yang dibantu dengan pemanasan menggunakan hot plate. Percobaan ini dilakukan dengan memvariasikan volume ammonium hidroksida yang ditambahkan yaitu $20 \mathrm{ml}, 25 \mathrm{ml}, 30 \mathrm{ml}, 35 \mathrm{ml}, 40 \mathrm{ml}$ dan 70 $\mathrm{ml}$.

\subsubsection{Preparasi Sampel}

Sampel limbah dihancurkan atau dipotong kecil-kecil sebelum dilarutkan, sampel yang sudah diperkecil ukurannya diambil sebanyak 5 gram dari setiap jenis sampel. Kemudian masing-masing sampel dilarutkan ke dalam larutan $\mathrm{HCl}$ 18\%. Pelarutan dilakukan di dalam ruang asam pada temperatur ruang $\left(27^{\circ} \mathrm{C}\right)$ selama beberapa menit sampai sampel aluminium terlarut seluruhnya.

2.2.3 Proses Pengambilan Kembali Aluminium dengan Metode Gravimetri.

Setelah pelarutan ditambahkan ammonium hidroksida $(\mathrm{NH} 4 \mathrm{OH})$ ke dalam hasil pelarutan dan menambahkan pereaksipereaksi lain yang sudah dilarutkan ke dalam aquades $250 \mathrm{ml}$ (seperti asam suksinat 5\%, 2 gram urea dan 5 gram $\mathrm{NH} 4 \mathrm{Cl}$ ). Setelah itu dilakukan pendidihan menggunakan hot plate pada temperatur sekitar $90 \mathrm{oC}$ selama 1,5 jam sebagai proses penuaan endapan (digestion). Pengendapan terjadi selama proses pendinginan berlangsung (sekitar 3 jam), kemudian endapan disaring dengan menggunakan kertas saring whatman no. 40 , karena diharapkan hasil akhirnya tidak dipengaruhi oleh berat kertas saring sisa pembakaran. Pembakaran endapan dilakukan pada suhu $750^{\circ} \mathrm{C}$ dengan menggunakan furnace selama 2 jam, kemudian didinginkan sampai suhu ruang dan ditimbang dengan mengggunakan neraca analitis.

\section{HASIL dan PEMBAHASAN 3.1 Pemilihan Pelarut}

Pada awal penelitian dilakukan pemilihan pelarut yang cocok untuk digunakan dalam proses pelarutan aluminium. Pelarut yang digunakan yaitu asam klorida $(\mathrm{HCl}) 36 \%$, asam sulfat (H2SO4) 98\% dan asam nitrat (HNO3) 70\%. Hasil kelarutannya dapat dilihat pada tabel no. 1

\begin{tabular}{|c|c|c|}
\hline \multirow{2}{*}{$\begin{array}{l}\text { Tabel } \\
\text { Jenis } \\
\text { Pelarut }\end{array}$} & \multicolumn{2}{|c|}{ no.1 Kelarytated dunganium } \\
\hline & $\begin{array}{l}\text { Kondisi } \\
\text { suhu kamar } \\
27^{\circ} \mathrm{C}\end{array}$ & $\begin{array}{l}\text { Dengan } \\
\text { pemanasan } \\
60{ }^{\circ} \mathrm{C}\end{array}$ \\
\hline $\begin{array}{l}\mathrm{HCl} \\
36 \%\end{array}$ & $\begin{array}{l}\text { Aluminium } \\
\text { larut } \\
\text { sempurna }\end{array}$ & $\begin{array}{l}\text { Aluminium } \\
\text { larut } \\
\text { sempurna }\end{array}$ \\
\hline $\begin{array}{l}\mathrm{HCl} \\
18 \%\end{array}$ & $\begin{array}{l}\text { Aluminium } \\
\text { larut } \\
\text { sempurna }\end{array}$ & $\begin{array}{l}\text { Alumunium } \\
\text { larut } \\
\text { sempurna }\end{array}$ \\
\hline $\begin{array}{l}\mathrm{H}_{2} \mathrm{SO}_{4} \\
98 \%\end{array}$ & $\begin{array}{l}\text { Aluminium } \\
\text { tidak larut }\end{array}$ & $\begin{array}{l}\text { Aluminium } \\
\text { larut } \\
\text { sempurna }\end{array}$ \\
\hline $\begin{array}{l}\mathrm{HNO}_{3} \\
70 \%\end{array}$ & $\begin{array}{l}\text { Alumunium } \\
\text { tidak larut }\end{array}$ & $\begin{array}{l}\text { Alumunium } \\
\text { tidak larut }\end{array}$ \\
\hline
\end{tabular}

Pada pengujian pelarut ini, penambahan asam klorida 36\% dapat melarutkan alumunium dengan cepat, reaksi ini menghasilkan buih pada larutan akibat dari pendesakkan gas $\mathrm{H} 2$ yang dihasilkan dari reaksinya. Reaksi berhenti ketika buih yang terbentuk menghilang dan logam alumunium tidak 
tersisa sama sekali, berarti reaksi pelarutan berlangsung sempurna.

\section{$3 \mathrm{H} 2(\mathrm{~g})$}

$$
2 \mathrm{Al}(\mathrm{s})+6 \mathrm{HCl}(\mathrm{aq}) 2 \mathrm{AlCl} 3(\mathrm{aq})+
$$

Pada pelarutan menggunakan asam sulfat 98\% yang dilakukan pada suhu ruang, pelarutan berlangsung secara lambat dan zat warna pada kaleng ikut larut dalam prosesnya. Tetapi bila dilakukan pemanasan, asam sulfat tersebut dapat melarutkan alumunium.

Pada proses pelarutan menggunakan asam nitrat $70 \%$ tidak terjadi reaksi pelarutan aluminium, hanya terjadi pelarutan zat warna yang terdapat pada kaleng saja. Demikian juga ketika dilakukan pemanasan, pelarut asam nitrat ini tidak dapat melarutkan aluminium.

Berdasarkan dari efektivitas waktu melarutnya aluminium hingga terlarut sempurna, maka dipilih asam klorida karena dapat melarutkan aluminium dengan cepat dibandingkan dengan asam sulfat dan asam nitrat. Pelarutan alumunium menggunakan asam klorida 36\% menghasilkan buih yang terlalu banyak sampai meluap dari wadah yang digunakan, maka dilakukan pengenceran asam klorida hingga konsentrasinya menjadi $18 \%$. Pada konsentrasi ini buih yang terbentuk tidak sampai keluar dari wadahnya, sehingga aman digunakan sebagai pelarut dan tetap dapat melarutkan aluminium dengan baik.

\subsection{Alumina yang dihasilkan dari jenis bahan baku (sampel) yang berbeda.}

Hasil alumina dari berbagai jenis bahan baku (sampel ) yang berbeda, seperti kaleng, cetakan kue, pie pans, pizza pans, loaf pans dan aluminium foil bekas bungkus makanan, dapat dilihat pada tabel no. 2 berikut ini..
Tabel no.2 Kandungan Alumina dari berbagai jenis sampel

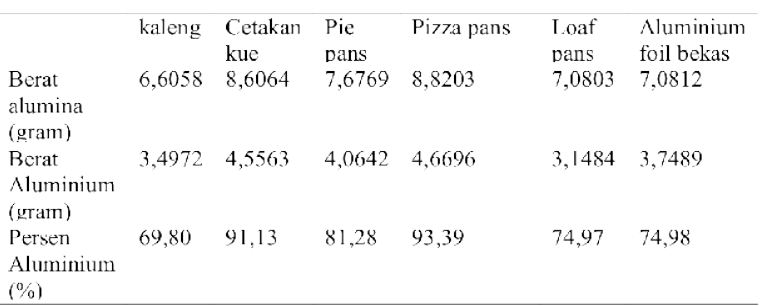

Pada tabel diatas terlihat bahwa perolehan alumina dari sampel yang berupa kaleng paling kecil dibandingkan dengan sampelsampel yang lain. Hal ini dapat disebabkan oleh kandungan $\mathrm{Al}$ dalam kaleng hanya $98,1 \%$, sisanya adalah $\mathrm{Mn} 1,2 \%$; Cu $0,5 \%$; $\mathrm{Fe}$ 0,7\% dan Si 0,6\% (Jenniri R, 2004). Sedangkan pada sampel yang berupa aluminium foil bekas juga terlihat rendah perolehan aluminanya, karena aluminium foil yang digunakan disini adalah aluminium bekas digunakan sebagai penutup bahanbahan kimia yang memungkinkan terjadinya reaksi antara bahan kimia tersebut dengan aluminium foil yang digunakan sebagai penutupnya.

Pada sampel lain seperti cetakan kue, pie pans dan pizza pans, perolehan aluminanya cukup tinggi, hal ini bisa disebabkan karena sampel yang digunakan disini masih baru belum dipakai, jadi kandungan aluminanya belum terganggu oleh proses pemasakan makanannya maupun proses pembuangannya sebagai limbah.

Dari perhitungan menggunakan massa atom relatif, didapat berat aluminium dari setiap sampel dan persen alumunium yang terkandung dari 5 gram masing-masing sampel dapat dilihat pada tabel no. 2, yaitu kaleng mengandung 69,80\%, cetakan kue $91,13 \%$, pie pans $81,82 \%$, pizza pans $93,39 \%$, loaf pans $74,97 \%$ dan alumunium foil $74,98 \%$.

\section{SIMPULAN DAN SARAN \\ 4.1 Simpulan :}

a. $\mathrm{HCl} 18 \%$ merupakan pelarut yang baik 
untuk melarutkan sampel yang mengandung alumunium pada suhu ruang $\left(27^{\circ} \mathrm{C}\right)$.

b. Kandungan alumina terbesar dari berbagai sampel adalah sampel pizza pans sebesar 8,8203 gram dari 5 gram sampel dengan persentase alumuniumnya sebesar $93,39 \%$.

\subsection{Saran :}

Walaupun recovery alumunium yang dilakukan dalam skala laboratorium ini dapat dilakukan dengan hasil yang cukup baik, tetapi kemurnian aluminanya masih harus dilakukan penelitian lebih lanjut.

\section{DAFTAR PUSTAKA}

1. Jenniri R. Majalah Widya volume 21 . No. 222. April 2004

2. Pujaatmaka, A.H. 1992. Analisis Kimia Kuantitatif (terj.). PT. Gelora Aksara Pratama Jakarta.

3. Penelitian PPTM \& Tekmira dengan CV.Radel Khalisan Alamindo. Bandung.

4. Vogel, S I. 1979. Text Book of Macro and semimicro Qualitative Inorganic Analysia. Longman Group Limited London.

5. Hawley, Gessnerg. 1981. The Condensed Chemical Dictionary., tenth edition. Volume 2. Van Nostrand ReinholdCompany.New York.

6. http://www.kompas.com:kompas edisi;Senin,14 Maret 2005;BM Lukita Grahadyarini.

7. Svehla, G dkk. 1985. Analisis Anorganik Kualitatif (terj). PT. Kalman Media Pustaka. Jakarta.

8. $\mathrm{https}: / / \mathrm{W}$ a w a s a $\mathrm{i} 1 \mathrm{~m} \mathrm{u}$ kimia,wordpress.com/2014/Aluminium -oksida-fungsi dan aplikasi

9.https://id.wikipedia.org/wiki/Aluminiumoksida

10. Dewi Ikmah. Laporan Tentang Aluminium dan Senyawa-Senyawa 